\title{
Clostridium tepidiprofundi sp. nov., a moderately thermophilic bacterium from a deep-sea hydrothermal vent
}

Correspondence

G. B. Slobodkina gslobodkina@mail.ru

\author{
G. B. Slobodkina, ${ }^{1}$ T. V. Kolganova ${ }^{2}$ T. P. Tourova, ${ }^{1}$ N. A. Kostrikina, ${ }^{1}$ \\ C. Jeanthon, ${ }^{3}$ E. A. Bonch-Osmolovskaya ${ }^{1}$ and A. I. Slobodkin ${ }^{1}$
}

\author{
${ }^{1}$ Winogradsky Institute of Microbiology, Russian Academy of Sciences, Prospect 60-letiya \\ Oktyabrya 7/2, 117312 Moscow, Russia \\ ${ }^{2}$ Bioengineering Center, Russian Academy of Sciences, Prospect 60-letiya Oktyabrya 7/1, 117312 \\ Moscow, Russia \\ ${ }^{3}$ UMR 7144, Adaptation et Diversité en Milieu Marin (AD2M), CNRS and Université Pierre and \\ Marie Curie, Place Georges Teissier, 29682 Roscoff Cedex, France
}

Among extreme environments, deep-sea hydrothermal vents contain large reservoirs of a wide variety of thermophilic and hyperthermophilic micro-organisms that belong to the Bacteria and Archaea. Micro-organisms from these environments use different metabolic pathways to grow; they may be chemolithoautotrophs, chemo-organoheterotrophs or mixotrophs (Jeanthon, 2000). Chemo-organotrophic, thermophilic, anaerobic bacteria isolated from these environments include members of the family Bacillaceae (L'Haridon et al., 2006) and the orders Thermotogales, 'Thermoanaerobacteriales' (Sokolova et al., 2001; Fardeau et al., 2004) and Clostridiales. The order Clostridiales includes a few thermophilic and moderately thermophilic species, namely Caloranaerobacter azorensis, Caminicella sporogenes, Tepidibacter thalassicus and Tepidibacter formicigenes (Wery et al., 2001; Alain et al., 2002; Slobodkin et al., 2003; Urios et al., 2004); only one moderate thermophile isolated from these environments, Clostridium caminithermale, has been

The GenBank/EMBL/DDBJ accession number for the 16S rRNA gene sequence of SG $508^{\top}$ is EF197795. classified as a representative of the genus Clostridium (in cluster XI) (Brisbarre et al., 2003). Microbiological investigations of deep-sea hydrothermal vents have concentrated largely on thermophilic and hyperthermophilic microorganisms and little attention has been paid to moderate thermophiles. In the present study, we report the isolation and characterization of an anaerobic, moderately thermophilic, fermentative bacterium (strain SG $508^{\mathrm{T}}$ ) originating from a deep-sea hydrothermal vent. We suggest that this strain represents a novel species of the genus Clostridium.

Strain SG $508^{\mathrm{T}}$ was isolated from a sample of the outer part of a chimney-like structure (black smoker) covered with tubes and specimens of the polychaetous annelid Alvinella sp. The sample was collected during the AMISTAD cruise at the $13^{\circ} \mathrm{N}$ hydrothermal field on the East Pacific Rise at a depth of $2650 \mathrm{~m}$ as described by Slobodkin et al. (2001). An enrichment culture was initiated by inoculation of $10 \%$ $(\mathrm{w} / \mathrm{v})$ of the sample into anaerobically prepared, bicarbonate-buffered, sterile $\left(135{ }^{\circ} \mathrm{C}, 1 \mathrm{~h}\right)$ liquid medium of the following composition (per litre distilled water): $0.34 \mathrm{~g}$ 
$\mathrm{KCl}, 4 \mathrm{~g} \mathrm{MgCl}_{2} \cdot 6 \mathrm{H}_{2} \mathrm{O}, 0.25 \mathrm{~g} \mathrm{NH}_{4} \mathrm{Cl}, 0.14 \mathrm{~g} \mathrm{CaCl}_{2} \cdot 2 \mathrm{H}_{2} \mathrm{O}$, $0.14 \mathrm{~g} \mathrm{~K}_{2} \mathrm{HPO}_{4}, 18 \mathrm{~g} \mathrm{NaCl}, 5 \mathrm{~g} \mathrm{NaHCO} 3,0.20 \mathrm{~g}$ yeast extract (Difco), $0.002 \mathrm{~g} \quad \mathrm{Fe}\left(\mathrm{NH}_{4}\right)_{2}\left(\mathrm{SO}_{4}\right)_{2} \cdot 7 \mathrm{H}_{2} \mathrm{O}, 10 \mathrm{~g}$ casein (Hammerstein grade), $1 \mathrm{ml}$ trace-element solution (Slobodkin et al., 1997), $10 \mathrm{ml}$ vitamin solution (Wolin et al., 1963), $0.001 \mathrm{~g}$ resazurin and $0.50 \mathrm{~g} \mathrm{Na} 2 \mathrm{~S} .9 \mathrm{H}_{2} \mathrm{O}$ $\left(100 \%\right.$ gas-phase $\left.\mathrm{CO}_{2}\right)$. A pure culture of strain SG $508^{\mathrm{T}}$ was obtained from a $50{ }^{\circ} \mathrm{C}$ enrichment culture by means of serial dilution in the same medium containing peptone $\left(10 \mathrm{~g} \mathrm{l}^{-1}\right)$ instead of casein followed by the selection of well-separated colonies that had developed in agar shake cultures $(1.5 \%$ agar in growth medium). Physiological studies on substrate and electron acceptor utilization and temperature, $\mathrm{pH}$ and salinity ranges for growth, light and electron microscopy, analytical techniques, DNA extraction and determination of $\mathrm{G}+\mathrm{C}$ content were performed as described by Slobodkin et al. (1999). $16 \mathrm{~S}$ rRNA gene amplification, sequencing and sequence analysis were performed as described by Zavarzina et al. (2002).

In agar-shake cultures, white, lens-shaped colonies (0.1$0.2 \mathrm{~mm}$ in diameter) of strain SG $508^{\mathrm{T}}$ appeared after 48 $72 \mathrm{~h}$ incubation at $50{ }^{\circ} \mathrm{C}$. Vegetative cells of strain SG $508^{\mathrm{T}}$ were straight to slightly curved rods, $0.4-0.6 \mu \mathrm{m}$ in diameter and $2.0-3.0 \mu \mathrm{m}$ in length. The cells occurred singly or in short chains, and had no flagella. When grown at below $\mathrm{pH} 5.5$, strain SG $508^{\mathrm{T}}$ formed round, refractile endospores in terminally swollen sporangia. Ultrathin sectioning of cells of strain SG $508^{\mathrm{T}}$ revealed a distinct peptidoglycan layer in the cell wall.

The temperature range for growth of strain SG $508^{\mathrm{T}}$ was $22-60{ }^{\circ} \mathrm{C}$, with optimum growth at $50{ }^{\circ} \mathrm{C}$. No growth was detected at $\leqslant 20$ or $62{ }^{\circ} \mathrm{C}$ after incubation for 3 weeks. The $\mathrm{pH}$ range for growth was 4.0-8.5, with optimum growth at between $\mathrm{pH} 6.5$ and 6.8. No growth was detected at $\mathrm{pH} 3.5$ or 8.9. Growth of strain $\mathrm{SG} 508^{\mathrm{T}}$ was observed at $\mathrm{NaCl}$ concentrations ranging from 1.0 to $6.0 \%(\mathrm{w} / \mathrm{v})$, with optimum growth at $2.5 \%(\mathrm{w} / \mathrm{v})$, but no growth was evident in the absence of $\mathrm{NaCl}$ or at $7.0 \%(\mathrm{w} / \mathrm{v})$. Substrates utilized by strain SG $508^{\mathrm{T}}$ included casein, peptone, tryptone, yeast extract, beef extract, starch (each substrate at $\left.10 \mathrm{~g} \mathrm{l}^{-1}\right)$, maltose and glucose (25 $\mathrm{mM}$ each). Pyruvate, L-valine, L-arginine (25 mM each), DL-alanine $(20 \mathrm{mM})$, L-proline $(10 \mathrm{mM})$, DL-alanine $(20 \mathrm{mM})+$ L-proline $(10 \mathrm{mM})$, glycine $(20 \mathrm{mM})$, DL-alanine $(20 \mathrm{mM})+$ glycine $(20 \mathrm{mM})$, fructose, xylose, cellobiose, sucrose, Larabinose ( $25 \mathrm{mM}$ each), glycerol, acetate, butyrate, lactate, formate, methanol, fumarate $(20 \mathrm{mM}$ each), betaine (5 mM), olive oil, xylan, CM-cellulose, filter paper, chitin (10 $\mathrm{g} \mathrm{l}^{-1}$ each) and $\mathrm{H}_{2} / \mathrm{CO}_{2}(80: 20$, v/v) were not utilized. All substrates were tested in the presence of $0.2 \mathrm{~g}$ yeast extract $1^{-1}$. In outgrown cultures in medium supplied with $25 \mathrm{mM}$ glucose, the products of glucose fermentation were ethanol $(3.6 \mathrm{mM})$, acetate $(2.9 \mathrm{mM}), \mathrm{H}_{2}(3.1 \mathrm{mM})$, formate $(0.8 \mathrm{mM})$ and $\mathrm{CO}_{2}$ (not quantitatively determined). Strain SG $508^{\mathrm{T}}$ reduced elemental sulfur $(150 \mathrm{mM})$ to hydrogen sulfide with peptone $\left(10 \mathrm{~g} \mathrm{l}^{-1}\right)$ as an electron donor, but sulfur reduction did not stimulate growth. Strain SG $508^{\mathrm{T}}$ was not able to utilize nitrate, fumarate, sulfate, thiosulfate ( $20 \mathrm{mM}$ each), sulfite $(5 \mathrm{mM})$, amorphous iron(III) oxide $(90 \mathrm{mM})$, iron(III) citrate $(20 \mathrm{mM})$ or oxygen $(20 \%, \mathrm{v} / \mathrm{v}$, in the gas phase) as electron acceptors with peptone $\left(10 \mathrm{~g} \mathrm{l}^{-1}\right)$ as an electron donor.

The G + C content of the genomic DNA of strain SG $508^{\mathrm{T}}$ was $30.9 \mathrm{~mol} \%\left(T_{\mathrm{m}}\right)$. A BLAST analysis revealed that strain SG $508^{\mathrm{T}}$ showed highest levels of $16 \mathrm{~S}$ rRNA gene sequence similarity with members of the genus Clostridium within the low-G $+C$ Gram-positive subdivision of the class Bacteria. A neighbour-joining comparison of $1464 \mathrm{nt}$ of the $16 \mathrm{~S}$ rRNA gene sequence of strain SG $508^{\mathrm{T}}$ with those available in the GenBank database showed that strain SG $508^{\mathrm{T}}$ belonged to cluster I of the genus Clostridium and related genera according to the nomenclature of Collins et al. (1994) (Fig. 1). Only 16S rRNA gene sequences of the type strains of recognized species were included in the analyses. The $16 \mathrm{~S}$ rRNA gene sequence of strain SG $508^{\mathrm{T}}$ showed highest similarity to those of the type strains of Clostridium pascui (92\%) and Clostridium sporogenes (91\%) (Wilde et al., 1997; Olsen et al., 1995). Levels of $16 \mathrm{~S}$ rRNA gene sequence similarity between strain SG $508^{\mathrm{T}}$ and the type strains of other members of phylogenetic cluster I were $90-91 \%$. Trees constructed based on the maximum-likelihood and maximum-parsimony algorithms displayed the same topology (data not shown). Transversion analysis (Woese et al., 1991) did not affect the phylogenetic position of the novel strain.

Cluster I of the genus Clostridium is the largest and the most phenotypically diverse of the clostridial groups. Although most members of this group are mesophiles, the group does include moderate thermophiles, namely Clostridium thermobutyricum and Clostridium thermopalmarium (Wiegel et al.,

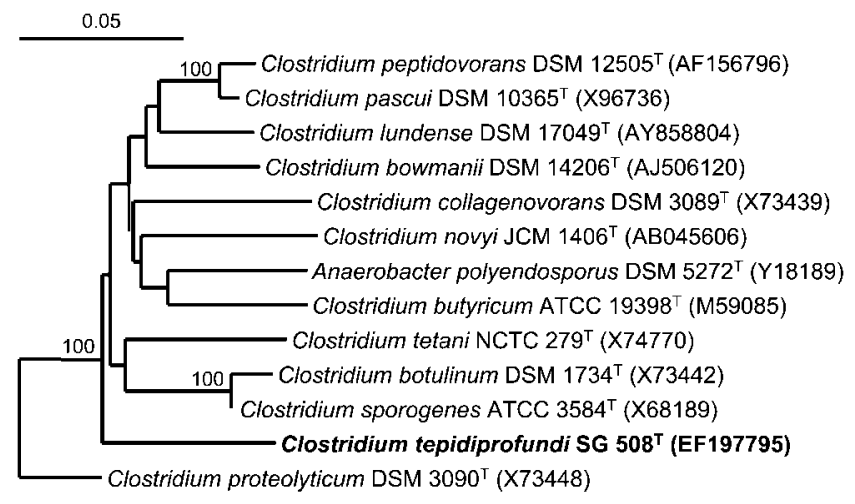

Fig. 1. Neighbour-joining phylogenetic tree based on $16 \mathrm{~S}$ rRNA gene sequences indicating the position of strain SG $508^{\top}$ within the radius of representative members of the genus Clostridium (cluster I). A representative member of cluster II (Clostridium proteolyticum DSM $3090^{\top}$ ) was included as an outgroup taxon. Bootstrap values are given at branch points (only values $>70 \%$ are indicated). GenBank accession numbers are given in parentheses. Bar, 5 substitutions per 100 nucleotides. 
1989; Soh et al., 1991), as well as a few psychrophilic species (Spring et al., 2003). Members of cluster I have been isolated from freshwater environments, with the exception of Clostridium oceanicum, which was isolated from marine sediments (Smith, 1970). Strain SG $508^{\mathrm{T}}$ shares morphological and physiological traits with members of cluster I of the genus Clostridium. The novel strain forms a separate branch on the phylogenetic tree and shows significant phylogenetic divergence from its closest relative, Clostridium pascui DSM $10365^{\mathrm{T}}$ (92\% $16 \mathrm{~S}$ rRNA gene sequence similarity). Strain SG $508^{\mathrm{T}}$ shows strictly anaerobic, organotrophic growth, and cells are rod-shaped and have the ability to form endospores. However, strain $\mathrm{SG} 508^{\mathrm{T}}$ is a moderately thermophilic marine bacterium, whereas its closest phylogenetic relatives are mesophilic bacteria that grow optimally in the absence of $\mathrm{NaCl}$. On the basis of its phenotypic and physiological properties, and based on current taxonomic guidelines, we suggest that strain SG $508^{\mathrm{T}}$ represents a novel member of cluster I of the genus Clostridium, for which the name Clostridium tepidiprofundi sp. nov. is proposed.

\section{Description of Clostridium tepidiprofundi sp. nov.}

Clostridium tepidiprofundi (te.pi.di.pro.fun'di. L. adj. tepidus moderately warm; L. n. profundum the depths of the ocean, N.L. gen. n. tepidiprofundi of the warm bottom of the ocean).

Cells are straight to slightly curved rods, $0.4-0.6 \mu \mathrm{m}$ in diameter and $2.0-3.0 \mu \mathrm{m}$ in length; spore formation is observed only at below pH 5.5. Cells form white lens-shaped colonies $(0.1-0.2 \mathrm{~mm}$ in diameter) in agar-shake cultures. The temperature range for growth is $22-60{ }^{\circ} \mathrm{C}$, with optimum growth at $50{ }^{\circ} \mathrm{C}$. The $\mathrm{pH}$ range for growth is 4.0-8.5, with optimum growth at $\mathrm{pH} 6.0-6.8$. Growth occurs at $\mathrm{NaCl}$ concentrations of $1.0-6.0 \%(\mathrm{w} / \mathrm{v})$, with optimum growth at $2.5 \%(\mathrm{w} / \mathrm{v})$. Anaerobic. Substrates utilized include casein, peptone, tryptone, yeast extract, beef extract, starch, maltose and glucose. Pyruvate, L-valine, L-arginine, DLalanine, L-proline, DL-alanine plus L-proline, glycine, DLalanine plus glycine, fructose, xylose, cellobiose, sucrose, L-arabinose, glycerol, acetate, butyrate, lactate, formate, methanol, fumarate, betaine, olive oil, xylan, CM-cellulose, filter paper, chitin and $\mathrm{H}_{2} / \mathrm{CO}_{2}$ are not utilized. The products of glucose fermentation are ethanol, acetate, $\mathrm{H}_{2}$, formate and $\mathrm{CO}_{2}$. Reduces elemental sulfur to hydrogen sulfide. Is not able to utilize nitrate, fumarate, sulfate, sulfite, thiosulfate, amorphous iron(III) oxide, iron(III) citrate or oxygen $(20 \%$, $\mathrm{v} / \mathrm{v}$, in the gas phase) as electron acceptors. The DNA G $+\mathrm{C}$ content of the type strain is $30.9 \mathrm{~mol} \%\left(T_{\mathrm{m}}\right)$.

The type strain, SG $508^{\mathrm{T}}$ (=DSM $19306^{\mathrm{T}}=\mathrm{VKM}$ B$2459^{\mathrm{T}}$ ), was isolated from a deep-sea hydrothermal vent chimney located at $13^{\circ} \mathrm{N}$ on the East Pacific Rise.

\section{Acknowledgements}

This work was supported in part by Federal programmes 'Molecular and cell biology' and 'The origin and evolution of the biosphere' of the Presidium of the Russian Academy of Science. The AMISTAD cruise was organized by CNRS with the NO L'Atalante and the DSV Nautile operated by IFREMER. We acknowledge the pilots and support team of Nautile and crew of L'Atalante.

\section{References}

Alain, K., Pignet, P., Zbinden, M., Quillevere, M., Duchiron, F., Donval, J.-P., Lesongeur, F., Raguenes, G., Crassous, P. \& other authors (2002). Caminicella sporogenes gen. nov., sp. nov., a novel thermophilic spore-forming bacterium isolated from an East-Pacific Rise hydrothermal vent. Int J Syst Evol Microbiol 52, 1621-1628.

Brisbarre, N., Fardeau, M.-L., Cueff, V., Cayol, J.-L., Barbier, G., Cilia, V., Ravot, G., Thomas, P., Garcia, J.-L. \& Ollivier, B. (2003). Clostridium caminithermale sp. nov., a slightly halophilic and moderately thermophilic bacterium isolated from an Atlantic deep-sea hydrothermal chimney. Int J Syst Evol Microbiol 53, 1043-1049.

Collins, M. D., Lawson, P. A., Willems, A., Cordoba, J. J., FernandezGarayzabal, J., Garcia, P., Cai, J., Hippe, H. \& Farrow, J. A. E. (1994). The phylogeny of the genus Clostridium: proposal of five new genera and eleven new species combinations. Int J Syst Bacteriol 44, 812-826.

Fardeau, M.-L., Bonilla, M. B., L'Haridon, S., Jeanthon, C., Verhé, F., Cayol, J.-L., Patel, B. K. C., Garcia, J.-L. \& Ollivier, B. (2004). Isolation from oil reservoirs of novel thermophilic anaerobes phylogenetically related to Thermoanaerobacter subterraneus: reassignment of $T$. subterraneus, Thermoanaerobacter yonseiensis, Thermoanaerobacter tengcongensis and Carboxydibrachium pacificum to Caldanaerobacter subterraneus gen. nov., sp. nov., comb. nov. as four novel subspecies. Int J Syst Evol Microbiol 54, 467-474.

Jeanthon, C. (2000). Molecular ecology of hydrothermal vent microbial communities. Antonie van Leeuwenhoek 77, 117-133.

L'Haridon, S., Miroshnichenko, M. L., Kostrikina, N. A., Tindall, B. J., Spring, S., Schumann, P., Stackebrandt, E., Bonch-Osmolovskaya, E. A. \& Jeanthon, C. (2006). Vulcanibacillus modesticaldus gen. nov., sp. nov., a strictly anaerobic, nitrate-reducing bacterium from deepsea hydrothermal vents. Int J Syst Evol Microbiol 56, 1047-1053.

Olsen, I., Johnson, J. L., Moore, L. V. H. \& Moore, W. E. C. (1995). Rejection of Clostridium putrificum and conservation of Clostridium botulinum and Clostridium sporogenes. Request for an Opinion. Int $J$ Syst Bacteriol 45, 414.

Slobodkin, A., Reysenbach, A.-L., Strutz, N., Dreier, M. \& Wiegel, J. (1997). Thermoterrabacterium ferrireducens gen. nov., sp. nov., a thermophilic anaerobic dissimilatory $\mathrm{Fe}(\mathrm{III})$-reducing bacterium from a continental hot spring. Int J Syst Bacteriol 47, 541-547.

Slobodkin, A. I., Tourova, T. P., Kuznetsov, B. B., Kostrikina, N. A., Chernyh, N. A. \& Bonch-Osmolovskaya, E. A. (1999). Thermoanaerobacter siderophilus sp. nov., a novel dissimilatory Fe(III)reducing anaerobic thermophilic bacterium. Int J Syst Bacteriol 49, 1471-1478.

Slobodkin, A., Campbell, B., Cary, S. C., Bonch-Osmolovskaya, E. A. \& Jeanthon, C. (2001). Evidence for the presence of thermophilic $\mathrm{Fe}$ (III)-reducing microorganisms in deep-sea hydrothermal vents at $13^{\circ} \mathrm{N}$ (East Pacific Rise). FEMS Microbiol Ecol 36, 235-243.

Slobodkin, A. I., Tourova, T. P., Kostrikina, N. A., Chernyh, N. A., Bonch-Osmolovskaya, E. A., Jeanthon, C. \& Jones, B. E. (2003). Tepidibacter thalassicus gen. nov., sp. nov., a novel moderately thermophilic, anaerobic, fermentative bacterium from a deep-sea hydrothermal vent. Int J Syst Evol Microbiol 53, 1131-1134.

Smith, L. D. S. (1970). Clostridium oceanicum, sp. n., a sporeforming anaerobe isolated from marine sediments. J Bacteriol 103, 811-813.

Soh, A. L., Ralambotiana, H., Ollivier, B., Prensier, G., Tine, E. \& Garcia, J.-L. (1991). Clostridium thermopalmarium sp. nov., a moderately 
thermophilic butyrate-producing bacterium isolated from palm wine in Senegal. Syst Appl Microbiol 14, 135-139.

Sokolova, T. G., Gonzalez, J. M., Kostrikina, N. A., Chernyh, N. A., Tourova, T. P., Kato, C., Bonch-Osmolovskaya, E. A. \& Robb, F. T. (2001). Carboxydobrachium pacificum gen. nov., sp. nov., a new anaerobic, thermophilic, CO-utilizing marine bacterium from Okinawa Trough. Int J Syst Evol Microbiol 51, 141-149.

Spring, S., Merkhoffer, B., Weiss, N., Kroppenstedt, R. M., Hippe, H. \& Stackebrandt, E. (2003). Characterization of novel psychrophilic clostridia from an Antarctic microbial mat: description of Clostridium frigoris sp. nov., Clostridium lacusfryxellense sp. nov., Clostridium bowmanii sp. nov. and Clostridium psychrophilum sp. nov. and reclassification of Clostridium laramiense as Clostridium estertheticum subsp. laramiense subsp. nov. Int J Syst Evol Microbiol 53, 1019-1029.

Urios, L., Cueff, V., Pignet, P. \& Barbier, G. (2004). Tepidibacter formicigenes sp. nov., a novel spore-forming bacterium isolated from a Mid-Atlantic Ridge hydrothermal vent. Int J Syst Evol Microbiol 54, 439-443.

Wery, N., Moricet, J.-M., Cueff, V., Jean, J., Pignet, P., Lesongeur, F., Cambon-Bonavita, M.-A. \& Barbier, G. (2001). Caloranaerobacter azorensis gen. nov., sp. nov., an anaerobic thermophilic bacterium isolated from a deep-sea hydrothermal vent. Int J Syst Evol Microbiol 51, 1789-1796.

Wiegel, J., Kuk, S. U. \& Kohring, G. W. (1989). Clostridium thermobutyricum sp. nov., a moderate thermophile isolated from a cellulolytic culture, that produces butyrate as the major product. Int $J$ Syst Bacteriol 39, 199-204.

Wilde, E., Collins, M. D. \& Hippe, H. (1997). Clostridium pascui sp. nov., a new glutamate-fermenting sporeformer from a pasture in Pakistan. Int J Syst Bacteriol 47, 164-170.

Woese, C. R., Achenbach, L., Rouviere, P. \& Mandelco, L. (1991). Archaeal phylogeny: reexamination of the phylogenetic position of Archaeoglobus fulgidus in light of certain composition-induced artifacts. Syst Appl Microbiol 14, 364-371.

Wolin, E. A., Wolin, M. J. \& Wolfe, R. S. (1963). Formation of methane by bacterial extracts. J Biol Chem 238, 2882-2886.

Zavarzina, D. G., Tourova, T. P., Kuznetsov, B. B., BonchOsmolovskaya, E. A. \& Slobodkin, A. I. (2002). Thermovenabulum ferriorganovorum gen. nov., sp. nov., a novel thermophilic anaerobic endospore-forming bacterium. Int J Syst Evol Microbiol 52, 1737-1743. 